\title{
PELATIHAN PELAYANAN PRIMA TENTANG PERILAKU PEMBERI LAYANAN DI KELURAHAN SIDOMULYO BARAT KECAMATAN TAMPAN KOTA PEKANBARU
}

\author{
Trio Saputra ${ }^{1}$ dan Bunga Chintia Utami ${ }^{2}$ \\ ${ }^{1,2}$ Dosen Fakultas Ilmu Administrasi \\ Universitas Lancang Kuning \\ ${ }^{1}$ Email : trio_saputra@unilak.ac.id
}

\begin{abstract}
ABSTRAK
Tujuan pengabdian ini adalah memberikan pemahaman dan ketrampilan kepada aparatur kantor keluarahan sidomulyo barat kecamatan tampan tentang perilaku pemberi layanan. Materi yang diberikan mengenai peraturan Menteri Negara Pendayagunaan Aparatur Negara No 7 tahun 2010 tentang pedoman penilaian kinerja unit pelayanan publik, indikator yang dinilai dalam Penghargaan Citra Pelayanan Prima (CPP) yang digelar Kementerian Pendayagunaan Aparatur Negara dan Reformasi Birokrasi (Kemenpan-RB) menilai bahwa pelayanan prima dapat dilihat dari visi, misi, sumber daya dan sarana prasarana. tidak hanya dari sisi kemampuan dan kompetensi tetapi juga sikap dan perilaku SDM di lini terdepan layanan. Pengabdian ini dilaksanakan di kantor Kelurahan Sidomulyo Barat Kecamatan Tampan Kota Pekanbaru. Metode yang digunakan dengan memberikan materi pelatihan melalui persentasi dan pelatihan perilaku pemberi layanan. Capaian pengabdian ini adalah terlaksanaanya kegiatan pengabdian sesuai dengan yang diharapkan dengan adanya perubahan mindset aparatur sipil negara dalam melayanan masyrarakat, jumlah peserta pengabian ini sebanyak 12 orang aparatur sipil negara kantor kelurahan. Peserta mendapatkan pemahaman dan ketrampilan tentang perilaku pemberi pelayanan untuk mewujudkan pelayanan prima.
\end{abstract}

Kata kunci : perilaku pemberi layanan, pelatihan, kelurahan, aparatur sipil negara

\begin{abstract}
The purpose of this dedication is to provide understanding and skill to the office apparatus offices sidomulyo west of handsome district about the behavior of service providers. The material given on the regulation of the State Minister of Administrative Reform No. 7 of 2010 on guidelines for the appraisal of the performance of public service units, the indicators assessed in the Prime Services Service Award (CPP) held by the Ministry of Administrative Reform and Bureaucracy Reform (Kemenpan-RB) Prime can be seen from the vision, mission, resources and means of infrastructure. Not only in terms of ability and competence but also attitudes and behavior of HR in the forefront of service. This devotion is held in the office of the subdistrict of Sidomulyo Barat in the handsome sub-district of Pekanbaru city. The method used by providing training materials through the presentation and training of the service provider's behavior. The achievement of this devotion is the implementation of service activities in accordance with the expected with the change of mindset of state civil apparatus in serving society, the number of this propagation participants as many
\end{abstract}


as 12 civil servants of state office of kelurahan. Participants gain understanding and skills about the behavior of service providers to realize excellent service.

Keywords: behavior of service providers, training, kelurahan, civil state apparatus

\section{PENDAHULUAN}

Pelayanan Publik merupakan area perubahan Reformasi Birokrasi yang menjadi salah Prioritas Reformasi Birokrasi. Berbagai alat ukur yang telah ditetapkan oleh pemerintah pusat maupun daerah untuk dapat meningkakan kualitas pelayanan seperti predikat kepatuhan pelayanan publik, kompetisi inovasi, Peniaian Mandiri Pelaksanaan Reformasi Birokrasi (PMPRB), penilaian citra pelayanan prima, anugerah pelayanan prima yang diadakan kementerian/ lembaga dan lain sebagainya. Pemeringkatan pelayanan publik ini merupakan salah satu cara dalam memantau dan mengevaluasi kinerja pelayanan publik.. Hal itu merupakan amanat dari pasal tujuh ayat tiga (Presiden Republik Indonesia, 2009)

Pelayanan prima adalah bagian penting untuk meningkatkan citra pelayanan. Undang-Undang Nomor 25 tahun 2009 menyatakan bahwa pelayanan prima adalah pelayanan yang cepat, mudah, pasti, murah, dan akuntabel. Berdasarkan peraturan Menteri Negara Pendayagunaan Aparatur Negara No 7 tahun 2010 tentang pedoman penilaian kinerja unit pelayanan publik, indikator yang dinilai dalam Penghargaan Citra Pelayanan Prima (CPP) yang digelar Kementerian Pendayagunaan Aparatur Negara dan Reformasi Birokrasi (KemenpanRB) menilai bahwa pelayanan prima dapat dilihat dari visi, misi, sumber daya dan sarana prasarana.

Pelayanan Prima (excellence service) adalah suatu sikap atau cara karyawan dalam melayani pelanggan secara memuaskan (Brata, 2003). Definisi tersebut menjelaskan bahwa penerima layanan/ pelanggan merupakan faktor penting dalam unsur Pelayanan Prima. Kepuasan penerima layanan menjadi alat evaluasi bagi penyelenggara pelayanan publik.
Penerapan strategi pelayanan prima terkendala oleh minimnya kualitas SDM, tidak hanya dari sisi kemampuan dan kompetensi yang tidak memadai, tetapi juga sikap dan perilaku SDM di lini terdepan layanan (Dwiyanto, 2005). Kecenderungan seseorang untuk melakukan atau tidak melakukan suatu perilaku tertentu, sehingga sikap bukan hanya kondisi internal psikologis yang murni dari individu (purely psychic inner state), tetapi sikap lebih merupakan proses kesadaran yang sifatnya individual (Winardi, 2004). Sedangkan wujud dimensi perilaku birokrasi sebagai sikap dan tindakan dalam memberikan pelayanan administrasi, meliputi tiga dimensi yaitu kepedulian, kedisiplinan dan tanggungjawab kerja (Miftha Thoha, 2005).

Perilaku pelaksana pelayanan publik berbanding lurus dengan perilaku baik pelaksananya (Saputra, 2016). Penjelasan bahwa perilaku yang baik tercermin dari sikap yang harus dimiliki oleh pelaksana pelayanan, yaitu:

1. Adil dan tidak diskriminatif

2. Cermat

3. Santun dan ramah

4. Tegas, andal dan tidak memberikan keputusan yang berlarut-larut

5. Profesional

6. Tidak mempersulit

7. Tidak memberikan informasi yang salah atau menyesatkan dalam menanggapi permintaan informasi serta proaktif dalam memenuhi kepentingan masyarakat

8. Tidak menyalahgunakan informasi jabatan dan wewenang yang dimiliki

9. Sesuai dengan kepantasan

10. Tidak menyimpang dari prosedur(Tidak meminta imbalan)

Mengingat bahwa pentingnya pemahaman aparatur terhadap perilaku 
pelayanan maka Pengabdian ini akan berfokus perilaku pada pelayanan kelurahan. Hal itu mengingat Keputusan Menteri Pendayagunaan Aparatur Negara Nomor 63 Tahun 2003 Tentang Pedoman Umum Penyelenggaraan Pelayanan Publik dijelaskan bahwa Segala bentuk pelayanan yang dilaksanakan oleh instansi Pemerintah di Pusat, di Daerah, dan di lingkungan
Badan Usaha Milik Negara atau jasa, baik dalam rangka upaya pemenuhan kebutuhan masyarakat maupun dalam rangka pelaksanaan ketentuan peraturan perundangundangan. Selain itu, Aparatur Sipil Negara (ASN) yang bertugas di kelurahan merupakan sumberdaya terdepan dan terdekat yang melayani masyarakat. Beberapa layanan kelurahan dapat dilihat dari tabel berikut.

Tabel 1.1 Jenis dan Bentuk Layanan Kelurahan

\begin{tabular}{clll}
\hline No & \multicolumn{1}{c}{ Jenis pelayanan } & & \multicolumn{1}{c}{ Bentuk Pelayanan } \\
\hline 1. & Pelayanan administrasi penduduk & a. & Pelayanan Pembuatan \\
& & & Pengantar KTP \\
& b. & Pengantar Kartu Keluarga \\
& & c. & Pengantar Surat Nikah \\
& d. & Pengatar Akta Kelahiran \\
2. Penyelenggaraan pemerintahan dalam hal & a. & Pengatar Akta Kematian \\
& perizinan & b. & Pengantar Perizinan SITU \\
3. Melaksanakan Administrasi Pertanahan & a. & Pengantar SKT \\
& b. & Pengantar SKGR \\
4 Dan lain-lain & & \\
\hline
\end{tabular}

Sumber : Perda kota pekanbaru No.5 tahun 2008

Pengabdian ini dinilai penting karena pemerintah telah melakukan berbagai upaya untuk mendorong pemahaman terkait pelayanan prima tetapi kendala yang muncul adalah keterbatasan anggaran dan SDM yang mumpuni. Sehingga harapannya adalah dapat mengurangi keterbatasan tersebut. Banyak unit/lembaga yang melakukan kerjasama dengan konsultan ataupun perusahaan manajemen tetapi tidak semua unit/lembaga dapat melakukannya. Untuk mendapatkan pelatihan pelayanan prima, pemerintah daerah harus membayar sekitar Rp. 3.500.000/orang s.d 10.000.000/orang untuk paket ekslusif.

\section{TUJUAN DAN MANFAAT}

\section{Tujuan}

Tujuan dari kegiatan pengabdian kepada masyarakat ini adalah untuk memberikan pemahaman dan keterampilan kepada aparatur sipil negara kantor Kelurahan Sidomulyo Barat Kecamatan Tampan Kota
Pekanbaru tentang perilaku pemberi layanan untuk mewujudkan pelayanan prima.

\section{Manfaat}

Manfaat yang didapat dari pengabdian ini adalah menambah pengetahuan dan pemahaman aparatur sipil negara untuk memberikan pelayanan prima kepada masyrakat.

\section{PELAKSANAAN KEGIATAN}

\section{Permasalahan mitra}

a. Masih belum ada standar pelayanan prima yang diterapkan di kelurahan.

b. Masih ada aparatur yang belum memahami budaya melayani.

\section{Pemecahan masalah}

a. Memberikan materi pelayanan publik tentang tugas dan tanggung jawab aparatur dan sanksi yang diberikan apabila melanggar aturan tersebut. 
b. Memaparkan contoh perilaku pemberi layanan kepada masyarakat.

c. Memberikan panduan cara membuat standar pelayanan.

d. Memberikan kesempatan kepada peserta pelatihan untuk bertanya mengenai hal yang belum jelas selama pemaparan materi sehingga peserta semakin memahami dan mengerti tentang materi yang disampaikan.

\section{Strategi sasaran}

Sasaran pelaksanaan pengabdian ini adalah aparatur sipil negara kantor Kelurahan Sidomulyo Barat Kecamatan Tampan, yang seluruhnya hadir baik tenaga honor maupun ASN dalam pelaksanaan kegiatan ini.

\section{Metode kegiatan}

Metode yang digunakan dalam kegiatan pengabdian kepada masyarakat ini adalah dengan presentasi materi pelayanan publik secara langsung kepada aparatur sipil negara kantor kelurahan, menggunakan media proyektor untuk menampilkan slide materi sehigga dapat dilihat dan dimengerti oleh peserta. Setelah pemaparan materi peserta diberi kesempatan untuk bertanya sehingga apa yang dijelaskan oleh Tim Pengabdian dapat dipahami dengan baik.

\section{HASIL KEGIATAN}

Amanat

Undang-undang

1945

mengandung makna bahwa negara berkewajiban memenuhi kebutuhan setiap warga negara melalui suatu sistem pemerintahan yang mendukung terciptanya penyelenggaraan pelayanan publik yang prima dalam rangka memenuhi kebutuhan dasar dan hak sipil setiap warga negara atas barang publik, jasa publik, dan pelayanan administratif (Saputra, T., \& Herianto, 2014). Hal ini dijelaskan dalam penjelas Undangundang Nomor 25 Tahun 2009 Tentang Pelayanan Publik.

Konsep pelayanan prima yang sering digunakan privat sector mulai di adopsi oleh lembaga publik. Lembaga penyelenggara pelayanan publik saat ini didorong untuk melakukan pelayanan prima melalui salah satunya melalui perubahan perilaku yang dikenal dengan Perubahan Budaya Kerja dan mental aparatur. Perubahan perilaku dapat diawali dengan perubahan mindset. Perubahan mindset diterapkan melalui afirmasi, visualisasi dan hypnosis. perilaku dapat diterapkanjika didukung oleh organisasi penyelenggara. Organisasi penyelenggara berkewajiban menyelenggarakan pelayanan publik minimal harus memenuhi pelaksanaan, pengelolaan pengaduan masyarakat, pengelolaan informasi, pengawasan internal, penyuluhan kepada masyarakat dan pelayanan konsultasi.

Untuk itu kegiatan pengabdian ini penting dilaksanakan, agar perwujudan pelayanan publik yang berkualitas terwujud dengan merubah perilaku pelayanan aparatur, kegiatan ini berjudul "Pelatihan Pelayanan Prima tentang Perilaku Pemberi Layanan di Kelurahan Sidomulyo Barat Kecamatan Tampan Kota Pekanbaru" dilaksanakan pada hari jumat 10 Maret 2017 di ruangan aula kantor Kelurahan Sidomulyo Barat Kecamatan Tampan. Para peserta berkumpul jam 08.00 WIB dan melakukan registrasi. Acara dimulai 08.30 dengan dibuka oleh moderator dan sambutan oleh Lurah Sidomulyo Barat, kemudian dilanjutkan dengan penyampaian materi dilakukan oleh tim pengabdian kepada masyarakat dengan topik pelayanan prima tentang perilaku pemberi layanan. Pemaparan materi sampai pukul 11.00 WIB dan dilanjutkan dengan tanya jawab hingga jam 12.00 WIB. Pada sesi tanya jawab terdapat 3 penanya, yang pertama Sekertaris Lurah Widya, Staff Pelayanan dan Lurah Sidomulyo Barat. 


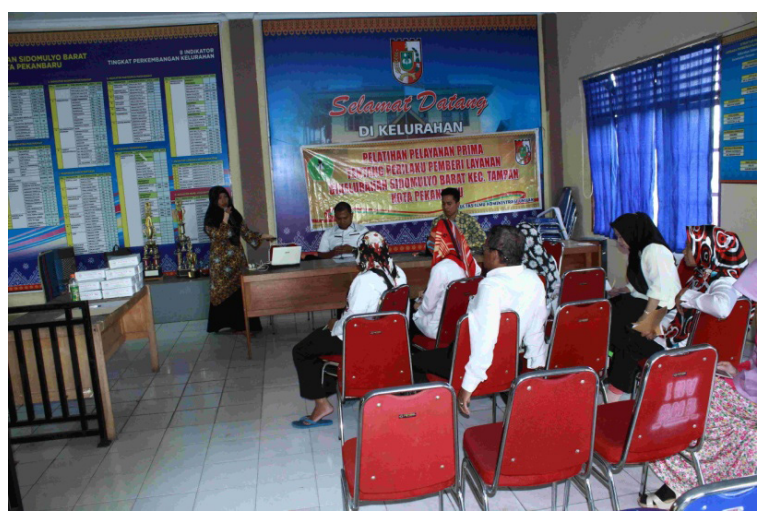

Gamba 4.1. Peserta pelatihan

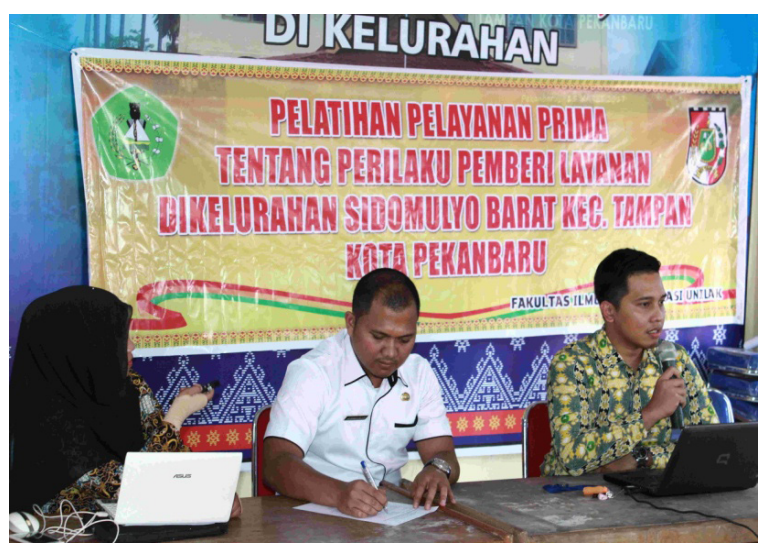

Gambar 4.2. Pembukaan Acara

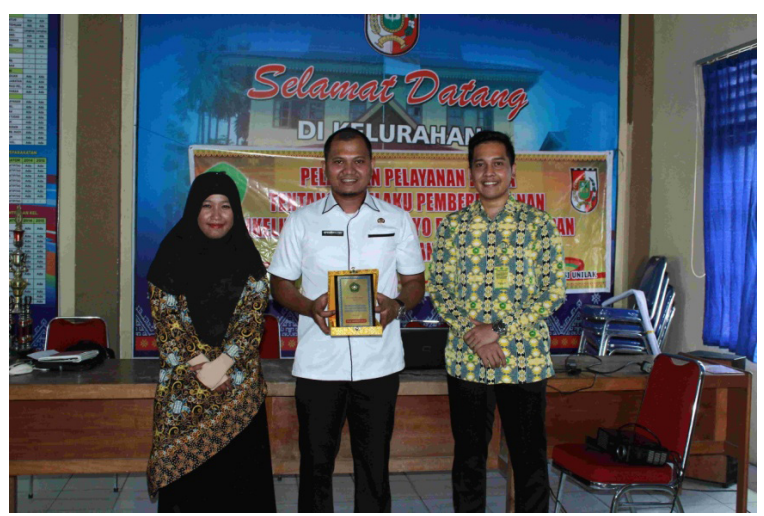

Gambar 4.3. Penyerahan Plakat kepada Lurah

\section{UCAPAN TERIMA KASIH}

Terima kasih penulis ucapkan kepada pihak yang membantu pelaksanaan pengabidan masyarakat dalam penyelenggaraan tri dharma perguruan tinggi. Diantaranya:

1. Fakultas ilmu administrasi universitas lancang kuning yang telah membiayai kegiatan ini sehingga terlaksana dengan baik serta memberikan manfaat kepada aparatur sipil negara.

2. Sebagai reviewer proposal pengabdian Ibuk surya dailliati S.Sos, M.Si, Ibuk Prihati S.Sos, M.Si dan Ibuk Hernimawati, S.Sos, M.Si yang telah memberikan masukan kepada tim pengabdian ini, untuk penyempurnaan kegiatan dilapangan.

3. Bapak lurah sidomulyo barat M. Randy Fajar S.IP yang telah menyediakan tempat dan memberikan kesempatan kepada tim pengabidan dalam melaksanakan pengabdian di kantor lurah.

4. Eka, S.Sos, M.Soc, Sc dan Pebriana Marlinda S.Sos, M.AP yang telah menghadiri acara pengabdian ini.

5. Seluruh Aparatur Sipil Negara kantor kelurahan yang berpartisipasi dalam mengikuti acara pengabdian ini sampai selesai.

\section{DAFTAR PUSTAKA}

Brata, A. adya. (2003). dasar-dasar pelayanan prima. Jakarta: Elex Media Komputindo.

Dwiyanto, A. (2005). Mewujudkan Good Governance Melalui Pelayanan Publik. Jogjakarta: Gajah Mada University Press.

miftha thoha. (2005). Perilaku Organisasi: Konsep Dasar Aplikasinya. Jakarta: gramedia pustaka. 
p ISSN: 1410-9344, e ISSN: 2549-5631

Presiden Republik Indonesia. (2009). undang-undang no. 25 tahun 2009 tentang pelayanan publik.

Saputra, T., \& Herianto, M. (2014). Komitmen organisasi, keadilan organisasi, dan kualitas pelayanan. Jurnal Administrasi Pembangunan, 2(2), 127-134.

Saputra, T. (2016). Kepuasan Masyarakat terhadap Penyelenggaraan Pelayanan Publik ( Studi Kasus Kantor Kecamatan Tambang Kabupaten Kampar ), 4(2), 89-100.

Winardi. (2004). Manajemen Perilaku Organisasi. Jakarta: Kencana Prenada Media Group. 